\title{
Determination of Foreign Direct Investment in Indonesia Development: Case Study Indonesia and Malaysia
}

\section{Ervina Rahmadila*}

Magister of Islamic Economic, Faculty of Economics and Islamic Business, Sunan

Kalijaga State Islamic University, Indonesia evirahmadila1105@gmail.com

\section{Halim Tri Rejeki}

Faculty of Economics and Islamic Business, Sunan Kalijaga State Islamic University, Indonesia

\section{Ibnu Muhdir}

Faculty of Economics and Islamic Business, Sunan Kalijaga State Islamic University, Indonesia

${ }^{*}$ Corresponding author

\begin{abstract}
Foreign Direct Investment (FDI) is one of the global economic systems. FDI is able to encourage the economic development of a country quickly, but there are problems that must be faced and of course become a challenge for the host countries, namely the presence of investors is strongly influenced by the internal conditions of a country, such as economic stability, state politics, law enforcement and others. This research investigates the relationship of macroeconomic variables to FDI in two countries namely Indonesia and Malaysia in the period 1989 to 2018. The method of analysis used Pooled Least Square (PLS). GDP variables have a positive but insignificant effect on the FDI levels in Indonesia and Malaysia. The test results on exports also showed the same thing that export variables give test results positive and insignificant influence on FDI variables.
\end{abstract}

Keywords: FDI, GDP, Indonesian, Malaysia

\section{INTRODUCTION}

The success rate of a country's development can be seen from the growth of its Gross Domestic Product (GDP). Indonesia and Malaysia's GDP can be exemplified, especially Indonesia, whose growth if viewed in aggregate is quite large, but when compared to the high population, it will get a low level of per capita income. So the government in this case needs to take appropriate action to boost economic development in time as soon as possible. One of the actions that has been taken by the government is to transform the economy, namely the exchange of the Indonesian economy, which was originally based on consumption, transformed into an economy based on investment (Bappenas, 2020).

Indonesia's Gross Dometic products in the period October 2017 to April 2020 fluctuated, but in general tended to decrease. This is evidenced in April 2019 Indonesia's GDP at 
$5.066 \%$ which was previously at 5.178\%, continuing to decrease dramatically in April 2020 to reach $-5.326 \%$ (IMF, 2020). Economic growth that continues to decline is certainly very concerning, this is also inseparable from the current global conditions that are being hit by the Covid-19 disaster. Based on the rill data can be concluded, Indonesia's economic development is currently experiencing a large shock so that additional capital from external parties is needed.

Foreign Direct Investment (FDI) is one of the global economic systems. A home country company invests its capital in the long term in a company in the host country by buying an existing company or providing capital to build a new company or buy a stake of at least 10\%. In particular, FDI can boost the country's economic development because there are several advantages, including; as a provider of jobs, can improve the implementation of import subsites to increase foreign exchange, encourage exports to get higher foreign exchange and build disadvantaged areas as well as supporting infrastructure, for industrialization and technology transfer (Susilo, 2018).

Although FDI is able to encourage the economic development of a country quickly, but there are problems that must be faced and of course become a challenge for the host countries, namely the presence of investors is strongly influenced by the internal conditions of a country, such as economic stability, state politics, law enforcement and others. Therefore, this research aims to review and analyze what factors can influence the high inflow of foreign direct investment in Indonesia and Malaysia.

Based on the description, it can be known that the problem formulation of this research is what are the factors that influence the level of FDI entry in economic development in Indonesia and Malaysia? This study aims to find out the influence of factors that influence the level of FDI entry in economic development in two countries, Namely Indonesia and Malaysia.

\section{THEORETICAL REVIEW}

Research on determinants of foreign direct investment (FDI) has a variety, both in the use of research methods and the results obtained. Transportation variables have a positive effect with FDI inflows (Sajilan et al., 2019; Hana et al., 2018). The most commonly used variables in researching FDI is Gross Domestic Product (GDP) which has a positive influence on FDI as done by (Hana et al., 2018; Fazaalloh, 2019; Sajilan et al., 2019; Razmi \& Behname, 2012, Khamis et al., 2015; Rahayu et al., 2017; Cahyaningsih, 2015; Khondoker \& Kaliapa, 2010; Horas et al., 2019).

Economic Openness (total Export of imports to GDP) Is also used as a benchmark for FDI inflows, which the higher the level of Economic Openness will attract more FDI inflows, As some previous research shows a positive relationship to FDI (Sajilan et al.,2019; Beheshtitabar \& Irgaliyev, 2008). However, negative influences on FDI were found in a small part of previous research (Rahayu et al., 2017). Furthermore, inflation negatively 
affects FDI (Razmi \& Behname, 2012; Cahyaningsih, 2015; Khamis et al., 2015; Sajilan et al.,2019).

Exchange rate is one of the vareabels used in the Granger Causality Test model to analyze the reciprocal influence with FDI, where there is no exchange rate and FDI causality relationship (Meftah \& Abdelkader, 2019). The causality relationship between GDP and FDI in previous research states that there is a causality that is in the same direction between GDP and FDI (Hana et al., 2018; Fazaalloh, 2019) Institutional Skin Relations are negatively related to FDI inflows (Sajilan at al., 2019) but Abdelkarim \& Mariem (2015) states institutional indicators are positively related to FDI.

From several previous studies can be concluded that, the inflow of FDI in a country is influenced by several variables that have been tested their influence each of the different research objects using several different methods and different results. Therefore, in the next research that will conduct testing and analysis of determinants on FDI inflows in Indonesia and Malaysia in economic development in both countries by using the variables GDP, inflation, export, and imports.

\section{Foreign Direct Investment (FDI)}

Based on Law No. 25 of 2007 on investment, FDI is an activity of investing to conduct business in the territory of the Republic of Indonesia conducted by foreign investors, both those who use foreign capital fully and who are related to domestic investors. According to Krugman et al. (2020) the meaning of foreign direct investment is an international current in which companies from one country establish or expand their companies in other countries. Therefore, there is not only the transfer of resources but also the enforcement of control over companies abroad. FDI includes investment into real assets such as the construction of factories, procurement of various capital goods, land purchases for production, and so on.

\section{Gross Domestic Product (GDP)}

GDP is the most important concept compared to other national income concepts. GDP is also the value of goods and services produced within the country for a period of time. It includes the output of goods and services in an economy produced by companies owned by concerned citizens as well as foreign nationals domiciled in the country concerned.

\section{Inflation}

Inflation is a process of prevailing prices in the economy. The inflation rate (presentation of price increases) differs from one period to another and differs from country to country (Sukirno, 2000). In some contexts, the word inflation can be interpreted as an increase in the money supply that can be considered as the cause of rising prices. Some economists prefer this definition rather than argue that prices go up on their own. In 
other words, inflation is also a process of continuously decreasing the value of the currency.

\section{Export}

According to customs, export is the activity of removing goods from the customs territory. Customs Territory is the territory of the Republic of Indonesia which includes land, water and air space above it, as well as certain places in the Exclusive Economic Zone and Continental Shelf in which the Customs Law applies. Exported goods are goods issued from the customs territory. Exporter is a person who conducts activities to remove goods from the customs territory. Export customs notification is a statement made by a person in order to carry out customs obligations in the export field in the form of writing on a form or electronic data.

\section{Import}

Import is the activity of entering goods into the customs territory. Import transaction is trade by entering goods from abroad into Indonesian customs area by complying with the provisions of the applicable regulation. The legal basis of the regulation on Import Management is stipulated in the Decree of the Director General of Customs and Excise Number KEP-07/BC/2003. On the implementation guidelines of Customs Procedures in the field of imports and Decree of the Minister of Finance No. 453 / KMK.04 / 2002 on Customs Procedures in the field of imports.

\section{METHODOLOGY}

This study uses secondary data. Secondary data used is time series data from January 1989 to December 2018. The object of this research is FDI Level in two countries namely Indonesia and Malaysia. The affects are GDP, Inflation, Exports, and Imports. The data comes from the official website of the Central Statistics Agency, Indonesian Bank, the Ministry of Finance of the Republic of Indonesia, and the International Financial Statistics Agency. The analysis tool in this research is the regression analysis of panel data processed using EViews 9.0 program. Panel data is a combination of timeseries and cross-section data.

\section{RESEARCH RESULTS AND DISCUSSION}

Based on the test results using pooled least square method shows the results that GDP variables have a insignificant influence on the FDI levels in Indonesia and Malaysia. The test results on exports also showed the same thing that export variables give test results positive and insignificant influence on FDI variables. This means that higher levels of GDP and exports can boost economic development in the two countries. 
Furthermore for variable imports and inflation from PLS testing indicated results that had a negative and insignificant influence. This shows that the greater the import, the smaller the inflow of FDI from Indonesia and Malaysia. In accordance with the fact that many foreign investments still use raw materials from abroad and there are still few who use domestic raw materials for their production. Inflation variables show test results that have negative and insignificant effects. This influence can be interpreted that the higher inflation in Indonesia or Malaysia, the entry rate of FDI to the two countries is decreasing. This is because investors will be better off avoiding the risk of high inflation in the intended country.

Table 1. Statistics Test Result

\begin{tabular}{lrrrr}
\hline \multicolumn{1}{c}{ Variable } & Coefficient & Std. Error & t-Statistic & Prob. \\
\hline C & 1.855604 & 0.688857 & 2.693742 & 0.0093 \\
GDP & 0.008295 & 0.007444 & 1.114295 & 0.2700 \\
EXPORT & 0.139256 & 0.047878 & 2.908572 & 0.0052 \\
IMPORT & -0.014720 & 0.033574 & -0.438439 & 0.6628 \\
INFLATION & -0.076371 & 0.028838 & -2.648241 & 0.0105 \\
\hline R-squared & & 0.292872 & Mean dependent var & 2.661568 \\
Adjusted R-squared & 0.241445 & S.D. dependent var & 2.210207 \\
S.E. of regression & 1.924981 & Akaike info criterion & 4.227364 \\
Sum squared resid & & Schwarz criterion & 4.401893 \\
Log likelihood & 203.8053 & Hannan-Quinn criterion & 4.295632 \\
F-statistic & -121.8209 & Durbin-Watson stat & 0.834674 \\
Prob(F-statistic) & 5.694865 & & \\
\hline
\end{tabular}

Table 2. Multicoleniarity Test

\begin{tabular}{ccccc}
\hline \multicolumn{5}{c}{ Correlation } \\
\hline & GDB_ANNUAL & EKSPOR_US\$ & INFLATION & IMPOR_US\$ \\
\hline GDB_ANNUAL & 1 & -0.247771780962815 & -0.27174470120789 & -0.19746231095986 \\
EKSPOR_US\$ & -0.2477717809062815 & 1 & 0.1782081265619422 & 0.7466519750551753 \\
INFLATION & -0.27174470120789 & 0.1782081265619422 & 1 & -0.1254879744352792 \\
IMPOR_US\$ & -0.197462313095986 & 0.7466519750551753 & -0.1254879744352792 & 1 \\
\hline
\end{tabular}

To test the existence of a high correlation between independent variables which can only be tolerated only up to $70 \%-80 \%(0.7-0.8)$. So from the table of test results shows that there is still a relationship (correlation that can be tolerated) or it can be concluded that there is no problem of Multicoleniarity. 
Table 3. Heteroscedasticity tests

\begin{tabular}{|c|c|c|c|}
\hline \multicolumn{4}{|c|}{ Heteroscedasticity Test Breush-Pagan-Godfrey } \\
\hline F-statistic & 1.176 .907 & Prob. F (4.55) & 2.299305556 \\
\hline Obs*R-squared & 4.730 .679 & Prob. Chi-Square (4) & 2.195138889 \\
\hline Scaled explainde ss & 7.791 .280 & Prob.Chi-square (4) & 0.690972222 \\
\hline
\end{tabular}

Heteroscedasticity tests are used to determine whether or not there are deviations of classical assumptions. Heteroscedasticity is the inequality of residual variants for all observations on regression models. A prerequisite that must be met in the regression model is the absence of symptoms of heteroscedasticity. If the prob value $<0.05$ then there are symptoms of heteroscedasticity in the research model whereas if the prob value $>0.05$ then there are no symptoms of heteroscedasticity in the research model. From the results of heteroscedasticity test using Breusch-Pagan-Godfrey method, the prob value is $2,195>0.05$ so that it can be concluded that there are no symptoms of heteroscedasticity in the research model.

Table 4. Normality Test

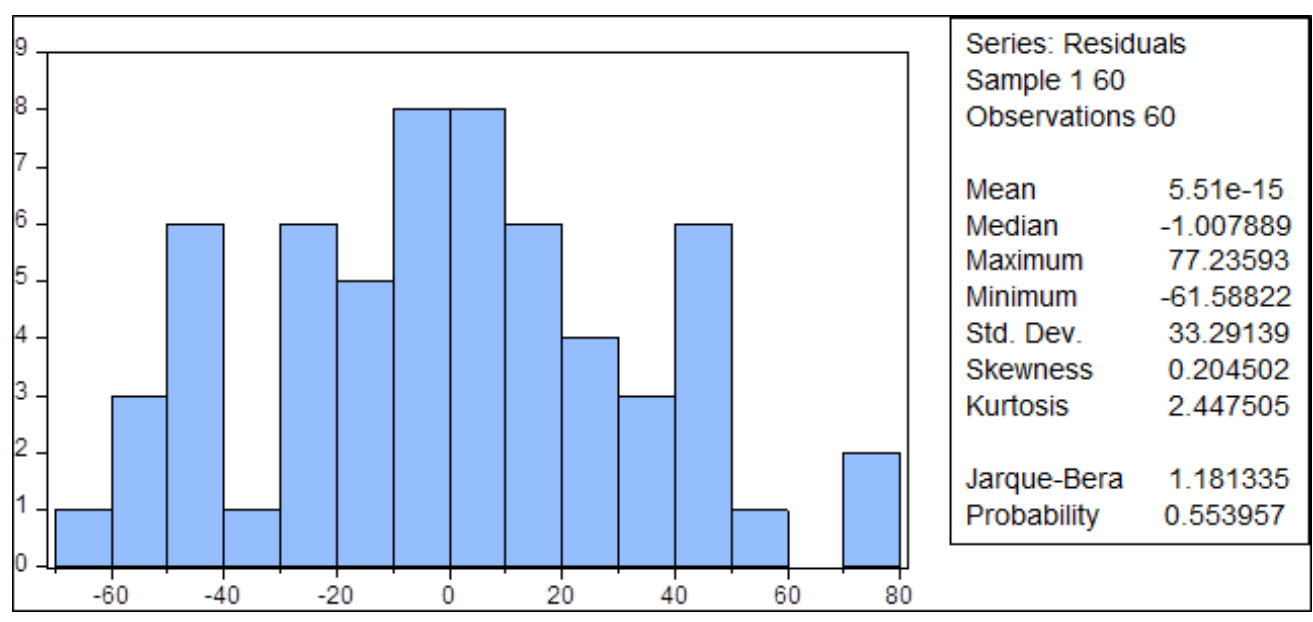

Test normality to test whether standardized residual values in regression models are normally distributed. How to perform normality test can be done with normal probability plot analysis approach. In this approach residual values are distributed normally when the lines (dots) depicting the real data will follow or close to the diagonal line. From the test results above, it can be seen that the probability value is $1.18>0.05$, meaning residual research data is distributed normally.

\section{CONCLUSION}

GDP variables have a positive but insignificant effect on the FDI levels in Indonesia and Malaysia. The test results on exports also showed the same thing that export variables give test results positive and insignificant influence on FDI variables. This means that higher levels of GDP and exports can boost economic development in the two countries. Variable imports and inflation from test results indicated results that had a negative and 
insignificant influence. This shows that the greater the import, the smaller the inflow of FDI from Indonesia and Malaysia. In accordance with the fact that many foreign investments still use raw materials from abroad and there are still few who use domestic raw materials for their production.

\section{REFERENCES}

Abdelkarim, Jabri \& Mariem Brahim. (2015). Institutional Determinants Of Foreign Direct Investment In MENA Region: Panel Co-Integration Analysis. Journal of Applied Business Research 31(5), 1-11

Bappenas. (2020). Rencana Kerja Pemerintah (RKP) Tahun 2021: Paparan Menteri PPN/Kepala Bappenas di Lemhanas RI. Jakarta.

Beheshtitabar, E., \& Irgaliyev, A. (2008). The Impact of Economic Freedom on FDI Inflows to Developing Countries: The Case of the Middle East. Gjuterigatan: Jonkoping Spring, 11-20.

Cahyaningsih, Nur (2015). The Analysis of Factors Affecting Foreign Direct Investment in Indonesian. Global Review of Islamic Economics and Business, 3(1), 59-72

Fazaalloh, Al Muizzuddin. (2019). Foreign Direct Investment and Economic Growth In Indonesia: A Causality Analysis. Jurnal Ekonomi Kuantitatif Terapan, [S.I.], 47-54.

Hana Raghdsifa A W, Hasdi Aimon, Mike Triani. (2018). Kausalitas Infrastruktur Transportasi, Foreign Direct Investment (FDI) Dan Pertumbuhan Ekonomi Di Indonesia. EcoGen, 1(3), 659-672

Horas Djulius, Choi Wongyu, J. Juanim, Raeni Dwi Santy. (2019). Nexus of Foreign Direct Investment, Domestic Investment, and Manufacturing Industry Value Added in Indonesia. Signifikan: Jurnal Ilmu Ekonomi, 8(1), 1-8

Khamis Hareb Alshamsi, Mohd Rasid bin Hussin and Muhammad Azam. (2015).The impact of inflation and GDP per capita on foreign direct investment: the caseof United Arab Emirates. Investment Management and Financial Innovations,12(3-1), $132-141$

Khondoker Mottaleb., Kaliappa Kalirajan (2010). Determinants of Foreign Direct Investment in Developing Countries: A Comparative Analysis. ASARC Working Paper 2010/13, 3-27

Krugman, Paul R., \& Maurice Obstfeld. (2000). Ekonomi Internasional Teori dan Kebijakan. (Faisal H. Basri, Penerjemah). Edisi 5. Jakarta: Indeks.

Meftah, Saliha \& Abdelkader Nassour. (2019). Macroeconomic Variables and Foreign Direct Investment Inflows in Turkey Signifikan: Jurnal Ilmu Ekonomi $8(2), 195-206$

Rahayu, Iriani Trisna., Pasaribu, Ernawati. (2017). Faktor-Faktor yang Memengaruhi Foerign Direct Investment (FDI) di Enam Koridor Ekonomi Indonesia: Market 
Seeking atau Resource Seeking?. Jurnal Aplikasi Statistika \& Komputasi Statistik, 9(1), 10

Razmi, M. J \& Behname, Mehdi (2012). FDI Determinants and Oil Effect on Foreign Direct Investment: Evidence from Islamic Countries. Advances in Management and Applied Economics, 2(4), 261-270

Sajilan, Sulaiman, Muhammad Umar Islam, Mohsin Ali, Urooj Anwar. (2019). The Determinants of FDI in OIC Countries. International Journal of Financial Research 10(5), 466-472

Sukirno, Sadono. (2020). Makroekonomi Teori Pengantar. Edisi 3. Jakarta: Raja Grafindo.

Susilo, D. (2018). The Impact of Foreign Direct Investment on Economic Growth (a Causal Study in the United States). BISE: Jurnal Pendidikan Bisnis dan Ekonomi, 4(1), 50-63. 